\title{
Analysis Validation of Math Learning Devices Based on Guided Discovery Method to Improve Problem-Solving Ability of Grade VII Students of Junior High School
}

\author{
${ }^{1 s t}$ Susanti \\ Mathematics Education \\ State UniversityPadang \\ Padang, Indonesia \\ chantyArnis68@gamil.com
}

\begin{abstract}
This research is research of development by using modified Plomp model, without including implementation phase. The device developed is RPP and LKPD. However, in this paper only focused on the validation test process through test validation constructs, language and content on the development of the device created. The end result of this research is to produce a valid learning device development product.
\end{abstract}

Keywords---validation, learning tool, Plomp model

\section{INTRODUCTION}

Education is a process of transforming learners in achieving certain things as a result of the process that followed. Education plays an important role in the process of intellectual life of the nation. However, the current situation of education providers still needs to improve themselves in achieving the goals of the national education system. The education system in Indonesia is generally still focused on cognitive intelligence. In accordance with the sound of Article 3 of Law No. 20 of 2003 on the National Education System that serves to develop the ability, shaping the character and civilization of a dignified nation in order to educate the nation's life, aims for the development of the potential of learners to become human beings who believe and piety to God The One, the noble, healthy, clean, capable, creative, independent, authoritative, and responsible.

The low learning outcomes of learners can be seen from the IMO results (International Mathematical Olympiad ) in 2017 held in Germany, Indonesia is ranked 31st of 111 countries participating. In addition, for the value of PISA (Program For International Student Assessment) which measures the literacy ability of reading, math, and science 15-year-olds in SMP / MTs / SMA / MA / SMK, Indonesia's score for math skills is 371 from an average score of 494. This shows the mathematical ability of Indonesian

\author{
${ }^{2 n d}$ I Made Arnawa \\ Mathematics Education \\ Andalas University \\ Padang, Indonesia \\ arnawa1963@gmail.com
}

learners still below International standards. From the results of the research obtained it can be interpreted the need for improvements to improve the results of learning mathematics.

Mathematics is a science that is structured and closely related to other subjects. The subjects of mathematics consist of a variety of topics that are related to one another, not just between topics in mathematics, but also the interrelationships that occur between mathematics and other disciplines as well. In learning mathematics can train the way of thinking of learners in drawing conclusions, and can develop understanding of learners. If associated with the School, mathematical purposes can make the learner active so that it can draw a conclusion and be able to solve the problem.

In general, mathematical ability can be seen from the results of the 2015PESA survey show that Indonesia is still unable to show brilliant achievements in reading, science and math. PISA survey results in the field of mathematics shows that Indonesia occupies the 63 position of 69 countries. This is a very worrying position for the development and quality of Indonesian education in the eyes of the International. The low achievement of Indonesian students in this program is closely related to the learning that occurs in schools. Learning in schools has not familiarized learners to solve the problems included in the criteria of PISA. Problems PISA provides a lot of mathematical ability, one of which is problem-solving. Indonesian students have not been able to achieve good achievement in PISA so it can be concluded that the quality of education in Indonesia is still low based on the ability of the students.

Mathematics learning is expected that learners can facilitate learners in finding their own concept of the material in a guided manner. This can be done by teachers in developing a learning activity that encourages learners in using his mindset. For that thing that can be done in supporting the learning activity of learners in using the mindset is 
contained in the Learning Implementation Plan (RPP) and can be used one of the learning media by using teaching materials such as Student Work Sheets (LKPD). LKPD aims to assist learners in understanding the material and help teachers in enabling learners on learning activities, so that learners are more motivated to try to find problems in LKPD and discuss with friends. So, researchers designed a mathematical learning device based on a guided discovery method supported by LKPD so that the resulting learning can facilitate learners in finding concepts and be able to improve problemsolving skills.

Based on observations obtained in the field that mathematics learning tools consisting of RPP and LKPD not optimal. This can be seen from the RPP used that has not used a learning strategy that suits the needs of learners. Based on the problems faced by learners is the lack of mastering the concept, one of the strategies that can be used by teachers is by learning that can make learners find the concept itself. Teacher learning steps are still using routine activities, namely learners are given the concept, giving examples of problems, and doing the exercises contained in the package book. If this is done continuously then learners feel bored and less motivated at the time of learning. It is seen that learning tools have not encouraged learners in finding concepts and using their mindset, so that the purpose of learning mathematics has not been achieved.

Based on the fact observation also in the field many teachers who have not used the teaching materials that vary in the learning process. Teachers are still transfixed by using textbooks only. The teacher teaches the subject matter according to the order of the material contained in the book. In fact, teachers can create other teaching materials, one of teaching materials such as LKPD. However, teachers prefer to buy LKPD that is sold outside the school to complete the teaching materials, because teachers have not been able to design LKPD because teachers have limited time, limited funding ability to design LKPD that can create learning that makes learners active in learning.

Flat wake material is one of the mathematics learning materials that require the ability of learners in solving problems. This material is also very important because it is a prerequisite material for learning mathematics in the next level. Problem-solving skills related to waking up flat will be a provision for learners in solving problems in everyday life.

Learning that has been going on in school has not been optimal and can still be improved. Learning should not only present the basic concepts in mathematics learning but also improve the problem-solving ability of learners. This is in line with Thohari's opinion in Jimbon said that the ability to solve mathematical problems is the goal of the process of teaching and learning mathematics.

From that background, researchers want to develop a learning tool using modified plomp model, that is only until the validation stage. Each instructional model leads us to design learning that will help students to achieve the learning objectives, in this study the method used is guided discovery.

In the guided discovery the teacher can provide guidance, directives, statements to LKPD to arrive at a conclusion about the material being taught. LKPD given by teachers depends on the ability of learners and the topics studied [2].

Through learning by using guided discovery methods, learners are expected to be really active in learning so that they are able to find their own concepts and principles learned. Steps to be taken by the teacher in determining the guided discovery method are as follows (a) Formulate problems to be provided to learners with sufficient data, (b) The formulation of the problem should be clear. (c) From the data provided by the teacher, the learners prepare, process, organize, and analyze the data. This guidance should direct the learners to move in the direction they want to go, through questions or Student Worksheet (Activity Sheets of Learners). (d) Learners construct conjectures (forecasts) from the results of their analysis. (e) If deemed necessary, the conjecture that the student has made is examined by the teacher. (f) If it has been obtained certainty about the truth of the conjecture, then the verbalization of the conjecture should be submitted also to the learners to arrange it. (g) After learners have found what they are looking for, the teacher should provide additional exercises or questions to check whether the findings are true [3].

So with this method, learners are faced with situations where it is free to investigate and draw conclusions. Exposure, intuition, and trial anderror should be encouraged. The teacher acts as a guide, he helps learners to use the ideas, concepts, and skills they have learned before to gain new knowledge. Applying the right questions by the teacher will stimulate the creativity of learners and assist them in finding the new knowledge. This method requires a relatively large amount of time in its implementation, but the learning outcomes achieved are of course proportional to the time spent.

\section{METHODS}

This research is a development research that is the development of learning tools based on guided discovery to improve the ability to solve mathematics problems of students of class VII 
SMP. The device development model used is the Plomp model as shown below:

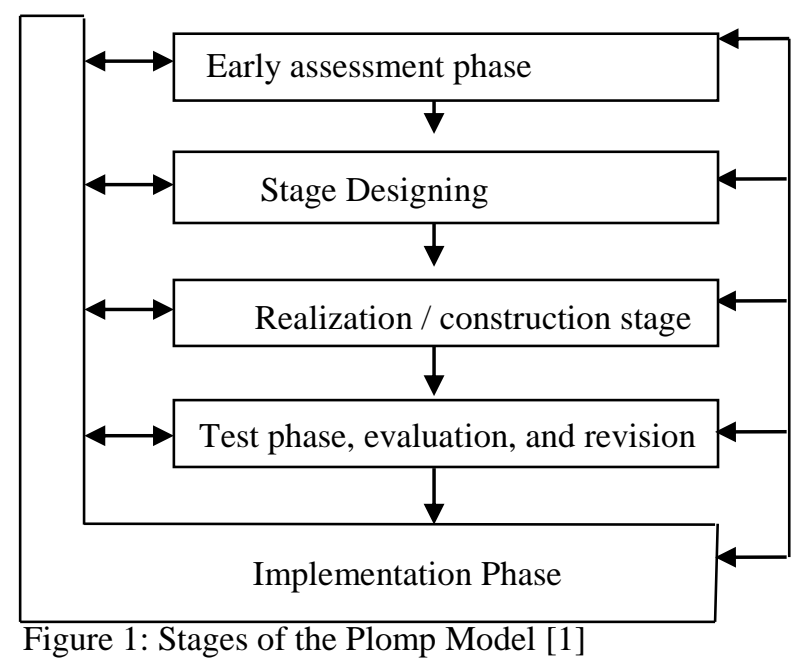

The drawings explain that the development stage of the device consists of five stages: (1) preliminary assessment, (2) design stage, (3) realization/construction stage, (4) test phase, evaluation and revision, and (5) implementation stage. However, in the implementation of this study using the modified Plomp development model into four stages [1].

\section{RESULTS AND DISCUSSION}

\section{A. Early assessment phase}

At this stage, identification or analysis is required in a learning device development based on guided discovery method. This stage is done by analyzing the objectives within the boundaries of the subject matter to be developed. The main steps that must be done (a) needs analysis, (b) curriculum analysis, and (c) conceptual analysis.

1) Needs Analysis

This analysis was conducted by interviewing a seventh-grade math teacher at SMPN 2 Koto Great on 11 December 2017. In the implementation of mathematics learning also conducted observations in class VII by using learning tools. Based on the results of interviews and observations that indicate the needs of learners in the form of new learning methods in addition to conventional learning that is able to optimize the problem-solving skills of mathematics learners.

Another need in implementing learning is learning tools for the learning process runs systematically to achieve the desired goals. Learning tools needed in the form of RPP and LKPD able to build the ability of problem-solving math problem students class VII SMP. Learning devices used in schools only aim to embed the basic concept only and have not been able to build the problem-solving skills of mathematics class VII junior high school students on the material wake flat, so it needs to be developed again so that RPP and LKPD are more qualified. Interview with mathematics teacher and observation result of learning implementation on preliminary analysis.

In addition to interviews and observations, questionnaires were conducted with 25 students on the characteristics of LKPD. Based on the results of questionnaires students class VII obtained that LKPD characteristics they want are with a display that matches the characteristics and is dominated by the blue color and paper size used is A4 size paper with the reason easy to carry anywhere. The result of the questionnaire of learner's preliminary analysis about LKPD characteristics desired. Thus, the needs of the learning device in question will be arranged in the development stage.

2) Curriculum Analysis

At this stage is done to the curriculum 2013 for the subjects of mathematics class VII SMP. This curriculum analysis analyzed core competencies and basic competencies that can be seen in content standards and learning objectives. The curriculum analysis is done by analyzing core competencies and basic competencies, material coverage, learning objectives, and indicators to be achieved. The results of the curriculum analysis are analyzed for the mathematics learning tools produced in accordance with the demands of competence that must be achieved by learners. The results obtained from the analysis of the content structure of the syllabus subjects seventh-grade math first semester II.

This analysis indicators such as the determination of the material class VII $g$ ponder half developed learning tools. Competency its core is to understand the knowledge (factual, conceptual and procedural) based on curiosity about science, technology, arts, culture and events related to the phenomenon of the visible. Its basic competence is to associate the circumferential and wide formulas for different types of rectangles (square, rectangle, rhombus, parallelogram, trapezoid, and kite) and triangles. Indicators to be achieved are to recognize and understand the rectangular and triangular, to understand the types and properties of rectangles, rectangles, trapezoids, parallelogram, rhombus and kites according to their nature, explaining the properties of square, rectangular, trapezoidal, parallelogram, diamonds and diagonals, explaining the types of triangles by their sides and angles, finding the type of triangle based on their properties, understanding the circumference and the area of the square, the rectangle, the trapezoid, the parallelogram, the rhombus and the kite- kite . Understanding the circumference and breadth of the triangle, solving problems in everyday life by using quadrilateral and triangular properties, understanding the special lines on the triangle, applying the concept of the circumference and the 
area of quadrilateral and triangle to solve the problem, solving the problem of flat-rectangular building, estimate the area of irregular flat.

The achievement of the indicator requires direction from the teacher. Teaching materials used should also be able to facilitate learners to be able to find understanding of the material in a guided manner, through various learning activities. Based on the translation of $\mathrm{KD}$, and this indicator compiled a mathematics learning device based on guided discovery method for SMP in the form of RPP and LKPD. Learning begins with learners can experience themselves in the discovery of a concept and the principle of the material so that stored in the memory of the learner.

\section{3) Concept Analysis}

Concept analysis aims to determine the content and subject matter needed in the development of learning tools. The material is needed to achieve the indicators of achievement of competence. Analysis of the concept aims to determine the content and subject matter needed in the development of learning tools of mathematics. After learning the material studied during the first semester of the first in class VII, it is necessary to analyze the concept with the aim of identifying the main concepts to be taught and systematically arranged according to the order of presentation. After analyzing the concepts based on the curriculum used there are 5 chapters namely integers, fractional numbers, algebraic arithmetical operations, equations and linear inequalities of one variable, comparison, and social arithmetic. $\mathrm{H}$ acyl Analyze the concept then only taken the material wake up flat as a learning device in the evaluation of mathematics. The given material must follow a logical path for all indicators to be achieved. The material that supports the indicators is described in more detail.

\section{B. Stage Designing}

From the initial investigative stage, we found the thinking in the device description, in this case, the researchers designed the RPP and LKPD that follow the characteristics of the guided discovery method developed: (1) contain guided discovery method steps. ( 2 ) contains the characteristics of RPP containing preliminary activities, core activities, and closing activities. and (3) LKPD characteristics that contain several aspects, namely content aspect, language aspect, and presentation aspect. Where this model according to the researcher can cover all the problems from the observation.

\section{Realization / construction stage}

The design of learning devices that have been completed then examined by the researchers themselves using the self-evaluation sheet. In general, many errors occur in typing words and punctuation. Punctuation errors for example, after punctuation are not spaced 1 spaces, lack of punctuation, letters are not capitalized after the dot. In LKPD typing errors, lack of fonts, text size accuracy, punctuation is lacking, the image on the problem 1 in LKPD 1. After doing the self evaluation, revision of the learning device. The result of this revision is called prototype I. Then prototype I results are consulted, discussed with experts or experts who are competent and validated.

D. Test phase, evaluation, and revision

1) Validation of Learning Implementation Plan (RPP)

RPP is the design of teachers before learning, there are some revisions that must be improved in order to produce a valid RPP, for inputs that have been given by experts and have been revised to the RPP can be seen in Table I.

TABLE I. REVISED RPP BASED ON VALIDATOR INPUT

\begin{tabular}{|l|l|}
\hline \multicolumn{1}{|c|}{ Before Revision } & \multicolumn{1}{c|}{ After Revision } \\
\hline $\begin{array}{l}\text { Notice again the methods, } \\
\text { models, and approaches to } \\
\text { learning are adjusted }\end{array}$ & $\begin{array}{l}\text { Guided discovery method, } \\
\text { cooperative learning model, } \\
\text { and problem-solving } \\
\text { approach. }\end{array}$ \\
\hline $\begin{array}{l}\text { The learning objectives are in } \\
\text { accordance with guided } \\
\text { discovery methods }\end{array}$ & $\begin{array}{l}\text { Through guided discovery the } \\
\text { learner can calculate the } \\
\text { overall value, the value per } \\
\text { unit, and the partial value. }\end{array}$ \\
\hline $\begin{array}{l}\text { In fact, concepts, and } \\
\text { principles fit into the material } \\
\text { of each meeting }\end{array}$ & $\begin{array}{l}\text { Facts, concepts, and principles } \\
\text { have been adapted to the } \\
\text { mater }\end{array}$ \\
\hline $\begin{array}{l}\text { Why the model is different } \\
\text { and just one method only and } \\
\text { every meeting adjust but } \\
\text { change the sentence }\end{array}$ & $\begin{array}{l}\text { Guided discovery steps } \\
\text { formulate problems, analyze, } \\
\text { construct conjectures ( } \\
\text { forecasts), examine and } \\
\text { provide exercises to verify the } \\
\text { findings are true. }\end{array}$ \\
\hline $\begin{array}{l}\text { In the final activities of the } \\
\text { students do reflection is not } \\
\text { clear and what kind }\end{array}$ & $\begin{array}{l}\text { Reflecting it by giving } \\
\text { homework }\end{array}$ \\
\hline
\end{tabular}

Based on input RPP validators have been revised in accordance with the suggestions of the validator. In addition to providing advice, the validator also gave the assessment of RPP. RPP validation results show that for the value of each aspect is very valid. Overall the developed RPP is said to be very valid with $89.79 \%$. So it can be concluded that the RPP based guided discovery method is very valid.

\section{2) Validation (Student Activity Sheet) LKPD}

The LKPD assessment is based on indicators previously shared with the validator. Based on the results of expert validation, several revisions made to the syllabus can be seen in Table II. 
TABLE II. LKPD REVISIONS BASED ON VALIDATOR INPUT

\begin{tabular}{|l|l|}
\hline \multicolumn{1}{|c|}{ Before revised } & \multicolumn{1}{c|}{ After revision } \\
\hline $\begin{array}{l}\text { steps on guided discovery do } \\
\text { not need to be attached } \\
\text { because it confuses the learner }\end{array}$ & $\begin{array}{l}\text { guided discovery steps are } \\
\text { only in the form of questions. }\end{array}$ \\
\hline $\begin{array}{l}\text { Sebaiknya give introductory } \\
\text { sentence in finishing an } \\
\text { activity }\end{array}$ & $\begin{array}{l}\text { Already given an introductory } \\
\text { sentence in an activity. }\end{array}$ \\
\hline $\begin{array}{l}\text { The colors in the book to be } \\
\text { highlighted again so that the } \\
\text { motivation of children is } \\
\text { increasing. }\end{array}$ & $\begin{array}{l}\text { Interesting colors have been } \\
\text { added. }\end{array}$ \\
\hline $\begin{array}{l}\text { Consider again capital letter } \\
\text { writing and } \\
\text { language used more attention }\end{array}$ & $\begin{array}{l}\text { capital letters been adjusted } \\
\text { and } \\
\text { language that is fixed in } \\
\text { accordance with EBI rules }\end{array}$ \\
\hline
\end{tabular}

A good LKPD is a teaching material written in a good and understandable language, presented attractively with pictures and descriptions, the contents of LKPD describe something that matches the author's idea. Based on the input LKPD validators have been revised in accordance with the suggestions of the validator. In addition to providing advice, the validator also gave the assessment of LKPD. LKPD validation results show that for the content aspect obtained the average validity of $85.71 \%$ with the category is very valid, the language aspect $80.00 \%$ with the category is very valid, and aspects of $90.00 \% \%$ with the category is very valid. In general, the validity of LKPD is $88.57 \%$ with the very valid category.

\section{CONCLUSION}

The above discussion shows that the validation process of learning device development tools based on the guided discovery method to improve mathematics problem-solving ability of class VII students of SMP fulfills content validation, presentation and construct. It states that it has produced a valid learning tool.

\section{REFERENCES}

[1]Aminah, N. Pembelajaran Matematika dengan Performance Assessment Meningkatkan Kemampuan Pemecahan Masalah. Jurnal Logika Hal 80-84 Vol X Tahun VII Edisi Maret 2014 ISSN 216849995.

[2]Suherman, herman. 2004. Common TextBook Strategi Pembelajaran Matematika Kontemporer. Bandung: JICAUniversitas Pendidikan Indonesia (UPI).

[3]Markaban. 2006. Model Pembelajaran Matematika dengan Pendekatan Penemuan Terbimbing. Yogyakarta: Departemen Pendidikan $\quad$ Nasional. 